\title{
PRELIMINARY STUDIES OF AIRBORNE PARTICULATE EMISSIONS FROM THE AMPELLUM S.A. COPPER SMELTER, ZLATNA, ROMANIA
}

\author{
BEN J. WILLIAMSON, NICOLAE HAR, WILLIAM O. PURVIS \& \\ ANA MARIA RUSU
}

\begin{abstract}
Preliminary studies have been carried on the characterization of particulate emissions from the Ampellum S.A. copper smelter in the town of Zlatna, Romania. The particulates studied were collected on polycarbonate filters using air pump apparatus and on the surfaces of lichens. Mass of total suspended particulates (TSP) and PM10 varied from 19 to $230 \mu \mathrm{g} / \mathrm{m}^{3}$ and 3 to $146 \mu \mathrm{g} / \mathrm{m}^{3}$, respectively (PM10/TSP $=0.14$ to 1.0 ), depending on wind direction and proximity to the smelter. Particulates on collection filters from a site directly downwind from the smelter have a mean equivalent spherical diameter (ESD) of $0.94 \mu \mathrm{m}$ (s.d. 1.1) and are dominantly made up of material with the composition of anglesite $\left(\mathrm{PbSO}_{4}\right)$. The remainder of the material is a heterogeneous mixture of silicates and $\mathrm{Fe}-, \mathrm{Pb}$ - and $\mathrm{Cu}$-bearing phases. Particulates $>5 \mu \mathrm{m}$ ESD are rare on the TSP filters, mainly due to the restricted sampling durations possible with the equipment used $(<3$ hours). Particulates have therefore been studied in the lichen Acarospora smaragdula, which was growing on posts downwind from the smelter and which was found to contain high levels and a broader range of particulates compared with the filters $(<5$ to $100 \mu \mathrm{m}$ in diameter). Larger particles include 20-30 $\mu$ m diameter Fe-rich spherules, which occasionally have $\mathrm{Pb}$ - and $\mathrm{S}$-rich encrustations on their surfaces. The nature and possible health effects of the particulates are discussed and recommendations made for future studies.
\end{abstract}

Keywords: airborne particulates, heavy metals, Acarospora smaragdula, pollution, Zlatna (Romania)

\section{INTRODUCTION}

The town of Zlatna in the Apuseni Mountains of Romania has been recognized by the Romanian Government as one of its top ten pollution 'hot spots' (Bellig et al., 1999). The Ampellum S.A. copper smelter produces potentially toxic gaseous (mainly $\mathrm{SO}_{2}$ ) and particulate emissions, the latter containing high levels of $\mathrm{Pb}$ and other substances which may impact on human and environmental health (Williamson et al., 1998). An average blood lead level of $37 \mu \mathrm{g} / \mathrm{dL}$ was recorded in local children, with individuals ranging up to $70 \mu \mathrm{g} / \mathrm{dL}$, which are well above $10 \mu \mathrm{g} / \mathrm{dL}$ levels which may cause adverse health effects in children (U.S. Centers for Disease Control and Prevention, 1991). A joint project between the U.S. Agency for International Development and local government, industry and community groups has succeeded in reducing average blood lead levels in children to $28 \mu \mathrm{g} / \mathrm{dL}$, and amongst smelter workers 'few, if any, had levels exceeding the U.S. standard' (Bellig et al., 1999).

Important in future programs to reduce lead and other toxic element exposure is a better understanding of the physical and chemical properties of 
smelter particulate emissions and their environmental fate. Numerous studies have shown that the main factors in controlling the bioavailability of components from smelter particulates are mineralogical and chemical form and particle size (e.g., Rieuwerts and Farago, 1995; Spear et al., 1998; Williamson, 2001). The chemistry and mineralogy of airborne particulates largely determines particle surface properties and therefore reactivity and solubility, with solubility being a major factor controlling bioavailability of contained potentially toxic substances. Particle size is important, as smaller particles are more able to penetrate into the deepest regions of the lung where they may cause the most severe health effects. The larger surface area to mass ratio of smaller particles also increases their potential for surface reactions and their solubility (Richards, 1997). Different sizes and compositions of particles may be produced from different processes and with this information control measures can be targeted to maximize environmental vs cost benefits. For example, the main form of $\mathrm{Pb}$ in the handling of ore and concentrates is galena ( $\mathrm{PbS}$ ) whilst a wide range of $\mathrm{Pb}$ compounds may be produced from smelting operations, including $\mathrm{PbSO}_{4}$ and $\mathrm{PbO} \cdot \mathrm{PbSO}_{4}, \mathrm{PbO}$, $\mathrm{PbS}, \mathrm{PbCO}_{3},(\mathrm{PbO})_{2} \cdot \mathrm{PbCO}_{3}, \mathrm{~Pb}$ metal and $\mathrm{Pb}$ silicates (e.g. Rieuwerts and Farago, 1995, Sobanska et al., 1999). Spear et al. (1998) showed that levels of bioavailable lead are approximately seven times greater for $\mathrm{PbO}$ and $\mathrm{PbSO}_{4}$ than for PbS.

The aims of the preliminary study presented here are to describe methods being used to assess particle emissions from the Ampellum S.A. smelter. Primary particulates have been collected on the surfaces of filters using air pump apparatus operated over short sampling periods $(<200$ minutes). Two categories of particles were collected simultaneously, total suspended particulates (TSP) and PM10, particulate matter with an aerodynamic diameter $<10 \mu \mathrm{m}$. It was not viable from an economic or practical viewpoint to set up the apparatus over longer periods of time and therefore natural lichens were collected from 'downwind' of the smelter. These were found to have accumulated high levels of airborne particulates. Lichens are commonly used as natural biomonitors of the effects of air pollution including metal deposition with particulate trapping being the principle mechanism of metal accumulation (see Garty, 1993). The most tolerant and widespread lichen in the area of the smelter was the crust-like lichen Acarospora smaragdula (Wahlenb.) Massal. (Purvis et al., 2000). Acarospora species occur widely in metalliferous environments including mineralized rocks, spoil heaps and other environments enriched by metals and are excellent accumulators of a wide range of metals.

\section{THE SMELTER AND LOCAL ENVIRONMENT}

The Ampellum plant processes sulphide concentrates ( 35 to $40 \% \mathrm{Cu})$ containing varying amounts of $\mathrm{S}$ and metals, including $\mathrm{Au}, \mathrm{Ag}, \mathrm{Pb}, \mathrm{Zn}, \mathrm{S}, \mathrm{Bi}, \mathrm{Cd}$ and Mo. The works contains two smelter plants, a newer Outokumpu-type flash smelting furnace and an older reverberatory furnace, which produce 30,000 and 10,000 tones $\mathrm{Cu}$ per year respectively (Matousek, 1994). Essentially, in both plants, dried concentrates are mixed with flux $\left(\mathrm{SiO}_{2}\right)$ and fed into the furnace $\left(1200-1300{ }^{\circ} \mathrm{C}\right)$, to produce $\mathrm{SO}_{2}$, iron-silicate slags and sulphide matte. The matte 
is poured into converters (with addition of $\mathrm{SiO}_{2}$ ) where the iron and sulfur are oxidized to produce iron-silicate slag, $\mathrm{SO}_{2}$ and blister copper $(\sim 98 \% \mathrm{Cu})$. Metal 'contaminants' in the matte are either partitioned into the vapor phase or into the slag, depending on their vapor pressure. Particulates may be produced by thermal or physical agitation of materials and melts during the various production stages and by condensation of vapors. Exhaust gases from the flash furnace are cooled and passed through an electrostatic precipitator which, according to smelter management, is thought to remove around $60 \%$ of particulates. During the sampling period, the sulfuric acid plant was not functioning and therefore the $\mathrm{SO}_{2}$ from the flash and reverberatory furnaces and converters was being released directly into the environment via the stack. In $1996, \mathrm{SO}_{2}$ levels of up to $1305 \mu \mathrm{g} / \mathrm{m}^{3}$ (30 minute mean concentration) were recorded in Zlatna town, which is well above the World Health Organization recommended maximum of $500 \mu \mathrm{g} / \mathrm{m}^{3}$ (10 minute mean concentration).

The smelter lies within the Ampoi valley at $400 \mathrm{~m}$ altitude, surrounded on either side by hills rising to over $900 \mathrm{~m}$. The prevailing winds are westerly although smoke emissions from the smelter often sink to the valley floor, spread west and so envelop the town in a heavy sulphurous mist. Release of $\mathrm{SO}_{2}$ and metal-rich particulates causes acid precipitation and metal contamination for more than $30 \mathrm{~km}$ down wind from the smelter creating a 'lichen desert' where few lichens can exist (Bartok, 1982).

In local environmental studies, extremely high lead levels, between 50 and 4,000 ppm, have been reported from soil samples taken on the valley sides (Gurzău et al., 1995), being most strongly accumulated in the uppermost 'brown earth' horizon of forest soils (Preda et al., 1988). Locally grown turnips, cabbages and grass have been found to contain 536 ppm, 347 ppm and 1971 ppm lead respectively (Zahan et al., 1981), largely dependent on soil type (Keul et al., 1984).

\section{MATERIALS AND METHODS}

TSP and PM10 were collected from 9 localities within and downwind from Zlatna (Fig. 1), between $8^{\text {th }}$ and $12^{\text {th }}$ October 1998. TSP were collected using a J. D. Technical JD8T (UK) airborne particulate sampler operating at a flow rate of $5 \mathrm{~L} /$ minute $( \pm 2.5 \%)$. Particle collections were made onto $25 \mathrm{~mm}$ diameter pre-weighed Millipore Isopore polycarbonate filters (pore size $0.8 \mu \mathrm{m}$ ), which are non-hydroscopic ( $<0.24 \%$ hydration in 24 hours). For the collection of 'PM10', a J. D. Technical high volume air sampler was used operating at a flow rate of $30 \mathrm{~L} /$ minute. This was attached to a Negretti C-30 (UK) PM10 selective-inlet head housing a $0.67 \mu \mathrm{m}$ pore size pre-weighed Millipore Isopore polycarbonate filter. Sampling intervals of between 20 and 200 minutes were used, depending on wind direction and proximity to the smelter, in order to collect enough material for SEM whilst not plugging the filter. 


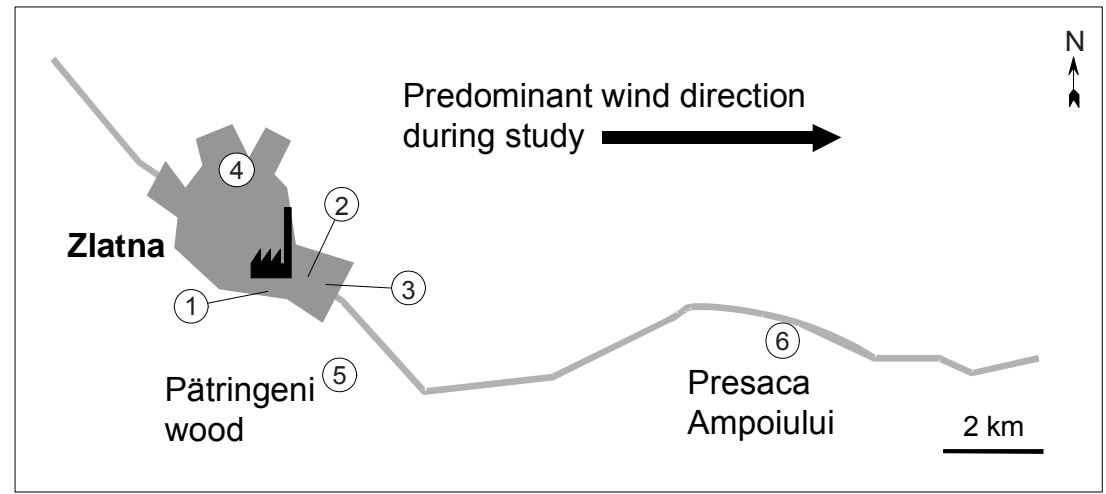

Fig. 1. Map of airborne particulate sampling points, using air pump apparatus.

Samples of Acarospora smaragdula (Wahlenb.) Massal. and their substrata were collected from concrete posts adjacent to the southern perimeter of unvegetated mine tailings within $400 \mathrm{~m}$ of the smelter (site 2 Fig. 1, coll. 18 July 1997, Purvis et al., 2000). Care was taken during removal of material to avoid contamination from rock dust. Samples were carefully wrapped in paper and stored in clean dry conditions.

For microprobe and SEM studies, small $\left(\sim 3 \mathrm{~mm}^{2}\right)$ samples of filter paper were cut out using a ceramic knife. These were mounted on sticky carbon tabs on aluminum $12.5 \mathrm{~mm}$ diameter SEM stubs (Agar, UK), and were carbon coated. Imaging and qualitative microprobe analyses of the particulates were carried out in a Jeol 5900LV SEM with INCA analysis system (SEM/EDX), at a working distance of $10 \mathrm{~mm}$, an accelerating voltage of $20 \mathrm{kV}$, a beam current of $\sim 1 \mathrm{nA}$ and with an analysis count time of 30 seconds. The data was processed using the quantification procedures in the INCA software (with an XPP correction procedure), mainly in order to deconvolute peaks where peak overlaps exist (such as for $\mathrm{Pb}$ and $\mathrm{S}$ ). Qualitative data for $\mathrm{Pb}$ vs $\mathrm{S}$ are shown on Fig. 3, to enable the study of inter-element relationships. Image analysis of images from the Jeol was undertaken in order to determine particle area for the calculation of equivalent spherical diameter $[E S D=2 \times \sqrt{(\text { area } / \pi}]$, which is the diameter of a perfect circle fitted to the measured area of the particle.

For X-ray element mapping of large $(>5 \mu \mathrm{m})$ particulates, material from the lichen surface was brushed onto a thin coat of ultra violate (UV) setting resin on a glass slide. The sample was ground down to a suitable cross section, polished using $0.3 \mu \mathrm{m}$ aluminum oxide, the sections carbon coated and loaded into an automated WDS Cameca SX50 microprobe. 'Beam' maps for small $(\sim 61 \times 61 \mu \mathrm{m})$ sample areas were generated (see Purvis et al., 2000) using an accelerating voltage of $15 \mathrm{kV}$, a beam current of $40 \mathrm{nA}$ and a spot size of $\sim 1 \mu \mathrm{m}$. Counts per second gain for each element determined were measured and plotted on separate maps using a continuously variable grey scale (Fig. 4). Quantitative analysis of the particles (points $A$ and $B$ in Fig. 4, Table 1 ) were carried out at an accelerating voltage of $15 \mathrm{kV}$, a beam current of $15 \mathrm{nA}$ and a spot size of $\sim 1 \mu \mathrm{m}$. 


\section{RESULTS}

Figure 2 shows mass ( $\mu \mathrm{g}$ dust per $\mathrm{m}^{3}$ air) of TSP compared with PM10 for the nine samples. The samples show large variations in TSP and PM10, ranging to levels above the EU 24-hour mean target value of $50 \mu \mathrm{g} / \mathrm{m}^{3}$ (to be met by $01 / 01 / 2010$ ). Most of the samples lie on a trend of about 3:1 TSP:PM10, however the samples from locality 4 lie on the 1:1 trend.

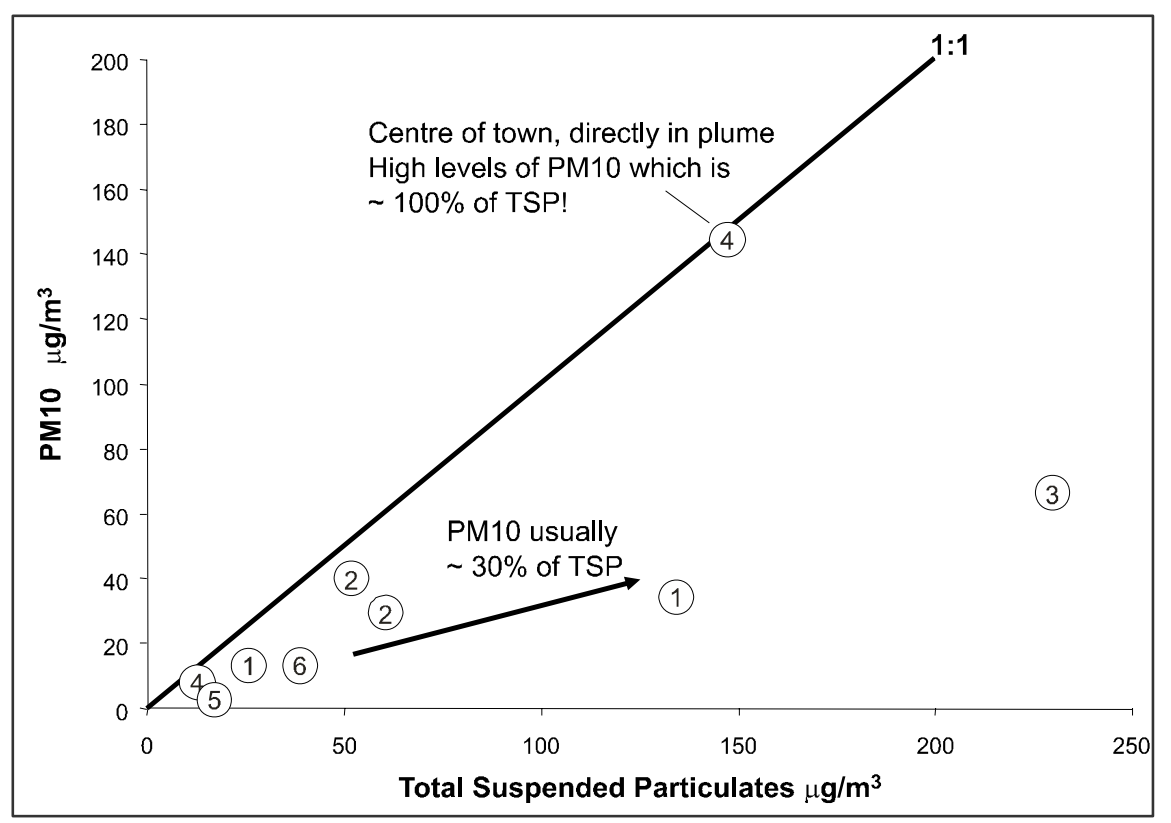

Fig. 2. TSP vs $P M 10 \mu \mathrm{g} / \mathrm{m}^{3}$ for particulates on collection filters from sites shown in Fig. 1. Nine filter samples were collected from the six sites shown in Fig. 1.

From a comparative study of two of the TSP filters, particulates are extremely heterogeneous in composition. One of the filters from site 2 contained only $4 \% \mathrm{~Pb}$-rich particles, the remainder being Al-silicates, commonly containing $\mathrm{Na}$ and $\mathrm{Ca} \pm \mathrm{Fe}, \mathrm{Mg}, \mathrm{K}, \mathrm{Ti}$, or were non-silicates containing $\mathrm{S}, \mathrm{Fe} \pm \mathrm{Cu}, \mathrm{Zn}$. The $\mathrm{Pb}$-rich particles were all less than $5 \mu \mathrm{m}$, mostly $<2 \mu \mathrm{m}$ and contained $\mathrm{S}$, and occasionally $\mathrm{Sn}, \mathrm{Zn}, \mathrm{As}$ and $\mathrm{Cu}$. Particulates on the filter from site 4, where PM10 levels were $146 \mu \mathrm{g} / \mathrm{m}^{3}$, were dominantly $\mathrm{Pb}$ - and S-bearing, with varying amounts of As and $\mathrm{Zn}$. Less than $10 \%$ were Al silicates, $\sim 1 \%$ Fe oxides, $\sim 0.5 \%$ chalcopyrite, and with $\sim 5 \%$ unknowns. From Fig. 3, the ratio of $\mathrm{Pb}$ to $\mathrm{S}$ in the particles can be seen to be fairly constant at around 6.5:1. This matches the stoichiometry of anglesite and galena (Fig. 3). From the relatively high ratio of $O$ to $S$ in the analyses, taking into account a contribution from the polycarbonate filter substrate, the particles are anglesite. This is not unexpected given the relatively oxidizing conditions in the furnaces and converter and the usual predominance of anglesite 
in smelter emissions (e.g. Rieuwerts and Farago, 1995). Greater than 50\% of the particles in this sample have anglesite compositions, although the exact proportion is difficult to assess more accurately as for many of the smallest particles insufficient counts were obtained in the microprobe analyses for reliable determinations of element ratios. The average ESD of the particles on the site 4 filter was $0.94 \mu \mathrm{m}$ (s.d. 1.1, $\mathrm{n}=115$ ).

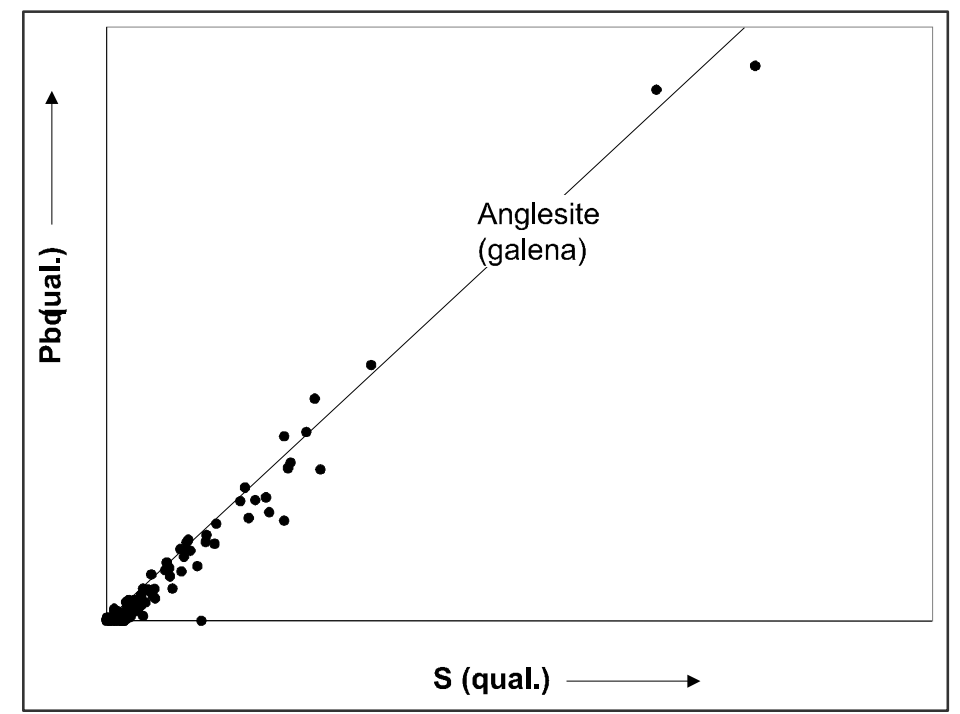

Fig. 3. $S$ vs $P b$ for particulates from site $4\left(P M 10=146 \mu \mathrm{g} / \mathrm{m}^{3}\right)$. The data is qualitative (qual.) since the sample surface is not flat or polished, and therefore no axis scales are shown. From studies of galena particles (PM10), the Pb to S ratio is meaningful and diagnostic.

Particulates trapped on the upper surface of the lichen range from $<5$ to $100 \mu \mathrm{m}$ in diameter, and are either spherical or subhedral to anhedral. The larger particles, $>5 \mu \mathrm{m}$, are mainly Fe-and Si-rich, containing varying proportions of $\mathrm{Al}$, $\mathrm{Na}, \mathrm{Ca}, \mathrm{Cu}, \mathrm{Pb}, \mathrm{Zn}, \mathrm{Mg}$, and a wide variety of trace elements, whilst others contain only $\mathrm{Cu}$ and $\mathrm{S}( \pm \mathrm{Fe})$, and are interpreted as representing sulfide glass from the molten matte. Many of the particles in the $<2 \mu \mathrm{m}$ size range, most of which are $\sim 500 \mathrm{~nm}$ in diameter, consist of $\mathrm{Pb}$ and S, very often with lesser amounts of $\mathrm{Sn}$ $( \pm \mathrm{Fe})$. Rare small particles are almost entirely made up of Ti or Sn.

X-ray element maps of a large, $\sim 30 \mu \mathrm{m}$ diameter, spherical particle are shown in Fig. 4. The particle can be seen to be zoned with a $\mathrm{Si}-, \mathrm{Cu}-, \mathrm{Pb}$-rich region separated by a sharp boundary from Fe-, Zn-rich areas. The sharp boundary would suggest that either the Fe- or Si-rich portions are crystalline. The compositions of the two main areas of the particle (at points $A$ and B, Fig. 4) are shown in Table 1. The Fe-rich portion has a hematite composition, with a small component of $\mathrm{Al}_{2} \mathrm{O}_{3}, \mathrm{CuO}$ and $\mathrm{ZnO}$, and it is probable that this material is crystalline. The Si-rich material contains high levels of a wide range of elements 
and is considered likely to represent glass. On the rim of the particle are irregular rounded regions rich in $\mathrm{Pb}$ and $\mathrm{S}$. Whether these represent primary particles from the smelter, similar to the anglesite composition particles, which adhered to the outside of the spherule, or were formed in situ (within the lichen) possibly from solution, is unclear.
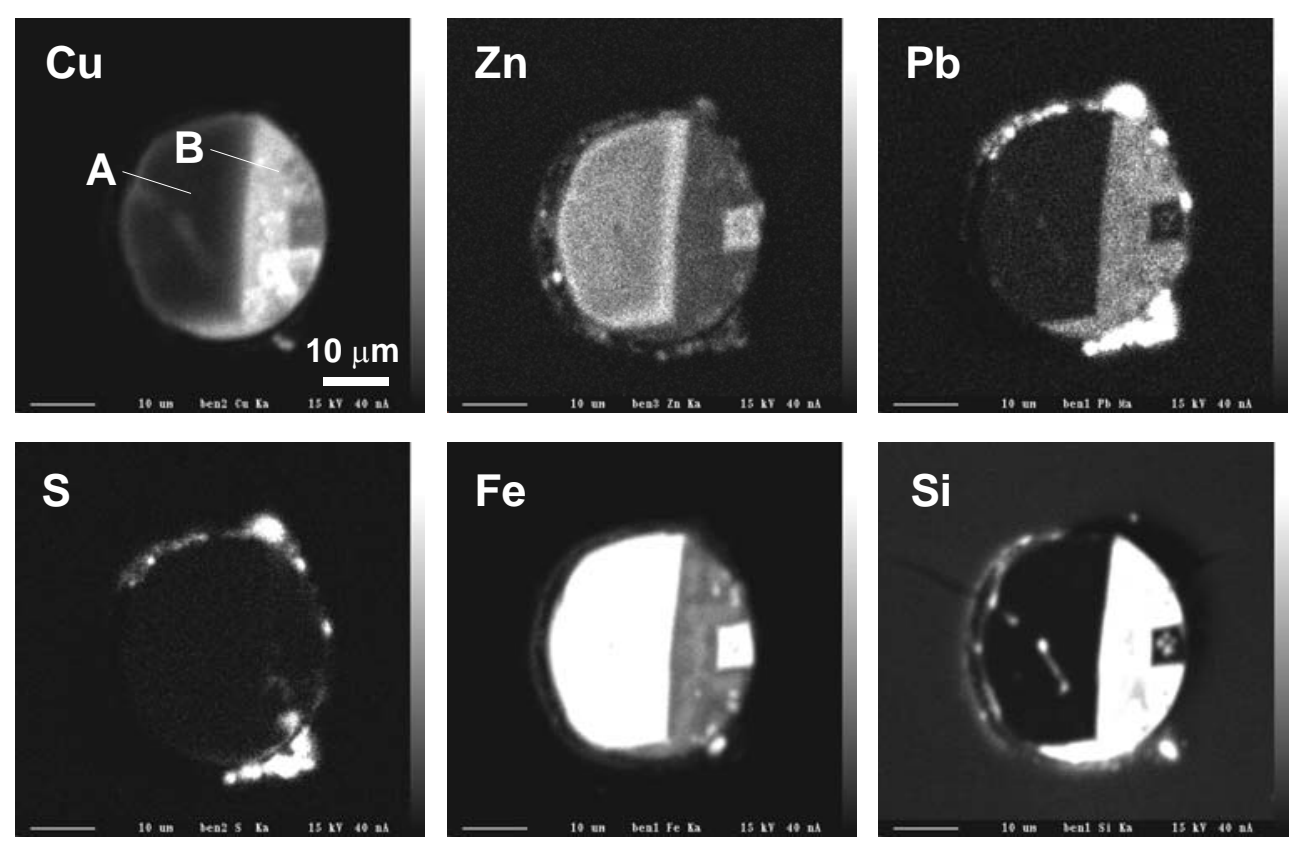

Fig. 4. X-ray element maps of a spherical particle from within a natural lichen sample collected downwind from the smelter (site 2, Fig. 1).

\section{DISCUSSION AND CONCLUSIONS}

High levels of PM10 have been recorded within the smelter plume, far exceeding the EU recommended maximum. From SEM studies, the average ESD of the particulates (TSP) was $0.93 \mu \mathrm{m}$, and they therefore fall well within the PM4 size class, known as the respirable fraction (Expert Panel on Air Quality Standards 2001). This is defined by the ISO as the mass fraction of inhaled particles, which penetrate the alveolar region of the lung (Quality of Urban Air Review Group, 1996), and may therefore cause the most severe health effects. The composition of the materials is predominantly that of anglesite $\left(\mathrm{PbSO}_{4}, \mathrm{Fig} .3\right)$ with trace amounts of $\mathrm{Zn}, \mathrm{Cu}$ and As. In sequential extraction studies on $\mathrm{PbSO}_{4}$ (in a $\mathrm{PbSO}_{4}-\mathrm{SiO}_{2}$ mixture), around $62 \% \mathrm{~Pb}$ was found to be exchangeable (1.0 M MgCl$, \mathrm{pH} 7.0,1 \mathrm{hr}$, $20{ }^{\circ} \mathrm{C}$, continuous agitation, Spear et al., 1998). The exchangeable fraction is 'exchangeable or soluble metals that occur as weakly absorbed ions on organic or mineral particle surfaces or forming soluble mineral, which are easily dissolved within an aqueous solution or exchanged by excess cations in solution'. It is likely 
therefore that a high proportion of anglesite composition particles, possibly up to $100 \%$ within the smelter plume, may be inhaled into the alveolar regions of the lung where the $\mathrm{Pb}$ will be in a form which is readily bioavailable. The inhalation of particles within the smelter plume should therefore be seen as a serious risk to human health and it is likely to contribute to the high blood $\mathrm{Pb}$ levels seen in local children.

From observations made during the period of the study, Zlatna town may often lie within the smelter plume, although no data was available to suggest exactly how often this occurs.

Particulates within the studied lichen samples are likely to have accumulated over long time periods (possibly 1 to 3 years or more). They therefore represent materials collected over a wider variety of conditions compared with the filter samples, most notably over different seasons, wind directions and when different smelter and related industrial activities were being carried out. This is consistent with the heterogeneous nature of the particles observed on the lichen surfaces, varying greatly in size, shape and composition. Spherical particles (e.g. Fig. 4) are likely to have been derived directly from smelter emissions while anhedral particles could also represent wind blown dusts from waste dumps and stockpiles of concentrates. The smallest particles, $<5 \mu \mathrm{m}$, appear to be similar in composition to the TSP filter samples, although this needs to be verified through more detailed studies. Although the larger particles are not so abundant as the smaller ones and will not be inhaled into the deep regions of the lung, they obviously contain a relatively high mass of potentially toxic elements and are therefore important from a more general environmental viewpoint. These may have complex internal chemical zonation (Fig. 4), and can consist of both crystalline and glassy material. The mineralogical and chemical compositions are major factors in determining the environmental fate of contained toxic metals, importantly their bioavailability. The particulates may breakdown into smaller size classes through physical mechanisms or as a result of weathering with subsequent chemical and mineralogical modifications. The particles, or components of the particles, can be inhaled or ingested through a variety of mechanisms, for example through re-suspension of dust by industrial and domestic processes such as sweeping or by road traffic, or through hand to mouth transfer. Particulates, and their breakdown products, may also contaminate livestock, water supplies and locally grown food crops, the latter shown to be significant in Zlatna by Zahan et al. (1981).

Table 1.

Microprobe analyses of different areas of a spherical particulate collected from within a sample of Acarospora smaragdula, the location of the points of analysis are shown in Fig. 4.

\begin{tabular}{cccccccccccccccc}
\hline & $\mathrm{Fe}_{2} \mathrm{O}_{3}$ & $\mathrm{CaO}$ & $\mathrm{TiO}_{2}$ & $\mathrm{PbO}$ & $\mathrm{Na}_{2} \mathrm{O}$ & $\mathrm{MgO}$ & $\mathrm{Al}_{2} \mathrm{O}_{3}$ & $\mathrm{SiO}_{2}$ & $\mathrm{SnO}$ & $\mathrm{CdO}$ & $\mathrm{CuO}$ & $\mathrm{ZnO}$ & $\mathrm{SO}_{3}$ & $\mathrm{As}_{2} \mathrm{O}_{3}$ & Total \\
\hline $\mathrm{A}$ & 87.57 & 0.13 & 0.11 & 0.00 & 0.00 & 0.20 & 2.29 & 0.18 & 0.14 & 0.00 & 4.07 & 2.18 & 0.00 & 0.04 & 96.91 \\
\hline $\mathrm{B}$ & 26.76 & 5.20 & 0.42 & 3.22 & 0.17 & 0.00 & 1.36 & 14.82 & 0.11 & 0.12 & 46.55 & 0.30 & 0.63 & 0.46 & 100.17 \\
\hline
\end{tabular}


From the preliminary studies presented here, is likely that particulate emissions from the Ampellum smelter may present a serious health risk to the local population. Recommendations for future studies include:

1) Re-sampling using air-pump apparatus to compare present day particle emissions with those in 1998;

2) Seasonal sampling to study the effects of differing meteorological conditions;

3) More detailed particle characterization to include a broader range of samples and analytical techniques, such at analytical TEM and X-ray diffraction;

4) Whole filter wet chemical analyses to determine levels of metals with were generally below the detection limits of the electron microprobe (e.g. Cd, As);

5) Sequential extraction studies to determine levels of bioavailable metals;

6) Atmospheric dispersion modeling to determine human exposure levels to particulates in different parts of the town and down wind where other populations may be affected.

7) Mapping of temporal and spatial patterns of metal deposition using a 'lowcost' lichen transplants.

Acknowledgements. We are grateful to Aron Dorin, Director of Ampellum S.A. smelter, for access to the site. We also wish to thank the British Council for funding two exploratory visits and the Royal Society for a Joint Project Research Grant. We thank Dr Chris Stanley for managing the project and the staff of the EMMA division (NHM) for technical support. We also thank Dr Tim Jones (Cardiff University) for the loan of PM10 sampling apparatus and for carrying out gravimetric determinations on the collection filters.

\section{REFERENCES}

Bartok K. 1982, Acumalarea plumbului şi manganului în lichenii din împrejurimile Zlatnei. Contrib. Bot. (Cluj-Napoca), 101-106.

Bellig P., Gurzău E., Vultur C., Stoica A., Filimon V. and Puşcaş M. 1999, Innovative intersectoral approach reduces blood lead levels of children and workers in Romania. Int. J. Occup. Environ. Health., 5: 50-56.

Expert Panel on Air Quality Standards 2001, Airborne Particles: What is the appropriate measurement on which to base a standard? A Discussion Document. Department for Environment, Food \& Rural Affairs, London, http://www.defra.gov.uk/environment/ airquality/aqs/air_measure/index.htm

Garty J. 1993, Lichens as biominitors for heavy metal pollution. In (B. Markert. Ed.) Plants as biomonitors. Indicators for heavy metals in the terrestrial environment: 191-263. Weinheim, Cambridge.

Gurzău E. S., Ponoran C., Ponoran S., Micka M. A., Billig P. and Silberschmidt M. 1995, Zlatna case study. In: Environment, Work \& Health in the New Central and Eastern European Democracies, Eforie, Romania, 24-26. 
Keul M. Lazăr-Keul G. and Vintilă R. 1984, Evaluarea efectelor poluării asupra unor esențe lemnoase prin analiza conținutului în glucide şi măsurători de creştere. Studia Univ. Babeş-Bolyai, Biol., 29: 269-274.

Matousek J. W. 1994, Environmental Health Project: Trip report: Technical visit to the copper smelter of Ampellum S.A. Zlatna, Transylvania, Romania. U.S. Agency for International Development (Report for the File No. 19).

Preda M., Keul M., Lazăr-Keul G., Vintilă R., Gallo St. and Piciu T. 1988, Auswwirkungen Langfristiger Umweltverschmutzungen auf die Blei-und Cadmiumanreicherungen in Böden. Contrib. Bot. (Cluj-Napoca), 269-274.

Purvis O. W., Williamson B. J., Bartok K. and Zoltani N. 2000, Bioaccumulation of lead by the lichen Acarospora smaragdula sens. lat. from smelter emissions in the town of Zlatna, Romania. New Phytologist, 147: 591-599.

Quality of Urban Air Review Group 1996, Airborne particulate matter in the United Kingdom. Department of the Environment 3, 30.

Rieuwerts J. S. and Farago M. E. 1995, Lead contamination in smelting and mining environments and variations in chemical forms and bioavailability. Chem. Spec. Bioavail., 7: 113-123.

Richards R. J. 1997, Small particles, big problems. Biologist, 4: 249-251.

Sobanska S., Ricq N., Laboudigue A., Guillermo R., Bremard C., Laureyns J., Merlin J. C. and Wignacourt J. P. 1999, Microchemical investigations of dust emitted by a lead smelter. Environ. Sci. Technol., 33: 1334-1339.

Spear T. M., Svee W., Vincent J. H. and Stanisich N. 1998, Chemical speciation of lead dust associated with primary lead smelting. Env. Health. Pers., 106: 565571.

U.S. Centers for Disease Control and Prevention 1991, Preventing Lead Poisoning in Young Children, A Statement by The Centers for Disease Control - October 1991, U.S. Department of Health and Human Services, Public Health Service.

Williamson B. J., Purvis O. W., Bartok K., Har N., Manolache E., John D. M., Stanley C. J. and Vlad N. Ş. 1998, Chronic pollution from minerals processing in the town of Zlatna, Apuseni Mountains of Romania. Stud. Univ. Babeş-Bolyai, Geol., XL1, 1: 87-93.

Williamson B. J. 2001, Mineralogical composition of atmospheric airborne particulates. Geology Today, 17: 32-35.

Zahan Z., Liuba G., Popa V. and Puşcaş G. 1981, Influența poluării atmosferei asupra plantelor alimentare dintr-o zonă industrială metalurgică. In: Suciu I. (Ed) Consecințe ecologice ale poluării cu metale grele. Lucrări şi Sinteze Ştiintifice, Sibiu, Mai 1981, $168-171$. 